\title{
Recent changes in biological availability of digoxin Effect of an alteration in 'Lanoxin' tablets
}

\author{
T. R. D. Shaw, M. R. Howard, and John Hamer \\ From the Department of Cardiology, St. Bartholomew's Hospital, London
}

Steady-state digoxin levels were recorded in patients using 'Lanoxin' (Burroughs Wellcome) tablets made before and after the recent change in the manufacture of this brand of digoxin tablet. Levels obtained with the newer Lanoxin tablets were two-thirds higher than those recorded with tablets produced before the change in manufacture. The biological availability of the most commonly used other brands of digoxin was similar to that of Lanoxin manufactured shortly before the change. Digoxin levels obtained with the newer Lanoxin are the same as those recorded with Lanoxin in 1969, just before an earlier alteration in the manufacturing process. It is recommended that the traditional digoxin dosage regimens be used for the latest Lanoxin.

Considerable variation is seen in the increase in digoxin levels of patients who have changed from tablets of low biological availability to the newer form of Lanoxin. Larger increases are seen under these circumstances in patients who absorb digoxin poorly. Patients changing to the newer Lanoxin should have their dosage completely reassessed.

It was recently announced that an amendment to the manufacturing process of 'Lanoxin' (Burroughs Wellcome) tablets had resulted in an increase in the amount of digoxin absorbed from the tablets (British Medical fournal, 1972; Lancet, 1972). This increase in the biological availability of the drug was thought to be approximately twofold. The increased biological availability of Lanoxin tablets was associated with a faster rate of release of the drug into solution as measured by dissolution tests in vitro (Beckett and Cowan, 1973; Fraser, Leach, and Poston, 1972).

Differences in biological availability had previously been reported between different brands of digoxin tablets (Manninen, Melin, and Härtel, 1971; Lindenbaum et al., 1971). We have found that, with some brands of digoxin tablet, crushing the tablet and administering the powder in a capsule gives more rapid absorption and much higher steadystate levels of digoxin (Shaw, Howard, and Hamer, 1972).

In this study we report the steady-state plasma levels of digoxin found during maintenance therapy with Lanoxin tablets made shortly before the recent manufacturing change ('older Lanoxin') and with Lanoxin tablets produced after the change ("newer Lanoxin'). These levels are compared with those

Received 12 July 1973. recorded in patients using other brands of digoxin tablets. We also report the change in digoxin level seen in a group of patients who used both the older and newer Lanoxin formulations. The dissolution rates of the brands used are given.

The 'Lanoxin' brand of digoxin is manufactured at several centres throughout the world. These results apply to Lanoxin tablets made in the United Kingdom.

\section{Patients and methods}

\section{Patients}

All the patients whose digoxin levels are reported here had normal or near-normal renal function (blood urea $<40 \mathrm{mg} / \mathrm{I} 00 \mathrm{ml}$ ).

During the period January to mid-June 1972 (i.e. before the newer Lanoxin became available), 73 patients attending a cardiac outpatient clinic had blood taken for plasma digoxin. In the great majority of patients, the blood sample was taken 6 to Io hours after the last digoxin dose. A few patients had blood taken 5 to 6 or Io to 18 hours after their last dose. Thirty-eight patients were using Lanoxin tablets and 35 patients used other brands.

Digoxin levels during use of the newer Lanoxin have subsequently been measured in 20 outpatients.

Plasma digoxin was also measured in 12 inpatients who had been on the same daily oral dose of newer Lanoxin for at least one week. In each case the blood 
sample was taken 6 to 12 hours after the last digoxin dose.

Cross-over group In 13 outpatients and 6 inpatients plasma digoxin levels were measured with both the older and the newer Lanoxin. The outpatients had been told of the importance of taking their tablets regularly and with a constant relation to meals. The inpatients had their drug records checked to ensure that they had been given each dose. The second plasma digoxin estimation was carried out one week after the change. The patients remained on the same daily dose of digoxin throughout. The batch of older Lanoxin used was 0953X. Two batches of newer Lanoxin were used, I483X and I579X.

\section{Methods}

Digoxin assay Plasma digoxin was measured by radioimmunoassay (Chamberlain et al., 1970). Repeated estimations of standard plasmas in the range 0.5 to 2.0 $\mathrm{ng} / \mathrm{ml}$ gave standard deviations of 0.05 to $0.1 \mathrm{ng} / \mathrm{ml}$.

Dissolution rate tests A total of 13 different brands were known to have been used by our patients and 9 other brands had been named by pharmacists who used several suppliers. A batch of tablets of the older and newer Lanoxin and 15 other brands were obtained from wholesale pharmacists. Samples of each type were submitted for in vitro measurement of dissolution rate. ${ }^{1}$ In each disolution rate test 6 tablets were used. The percentage of the total stated dose released into a 0.6 per cent hydrochloric acid solution by I hour was measured. Each dissolution rate test was done in duplicate. The method is to be published elsewhere.

\section{Results \\ Steady-state levels with different types of digoxin tablet}

The steady-state digoxin levels recorded with the older Lanoxin, the newer Lanoxin, and the group of other brands are shown in Table $I$ and the Fig. The digoxin levels found with the newer Lanoxin are approximately two-thirds higher than those obtained with the older Lanoxin. The differences at the 0.25 to $0.375 \mathrm{mg} /$ day and $0.5 \mathrm{mg} /$ day dosage groups are statistically highly significant $(P<0.001$, t-test). The levels in patients using other brands of digoxin tablets are similar to those found with the older Lanoxin. Table $I$ and the Fig. also show the digoxin levels recorded by Chamberlain and his colleagues (1970) in a similar group of patients on Lanoxin studied at this hospital in 1969. The levels found in 1969 are similar to those obtained with the newer Lanoxin.

\footnotetext{
1 The dissolution rate tests were carried out by Mr. A. C.
} Caws, The Wellcome Foundation, Dartford, England.

\section{Cross-over group}

Table 2 shows the steady state digoxin levels in 19 patients who used the same dose of both the older and newer Lanoxin. The mean level with the older Lanoxin was $0.86 \mathrm{ng} / \mathrm{ml}(\mathrm{SD} \pm 0.28)$ and the mean level with the newer Lanoxin $1.46 \mathrm{ng} / \mathrm{ml}$ (SD \pm 0.54 ), an overall increase of 70 per cent. This difference is statistically highly significant $(P<0.00 \mathrm{r}$, paired t-test).

Changing from older to newer Lanoxin produced an increase in plasma digoxin in each dosage group, but there were striking differences between the groups (Table 3). Patients in this group using 0.25 to $0.375 \mathrm{mg} /$ day older Lanoxin had a relatively high mean digoxin level of $0.87(S D \pm 0.18) \mathrm{ng} / \mathrm{ml}$ and showed only a moderate increase to $I \cdot I 7$ $(S D \pm 0.26) \mathrm{ng} / \mathrm{ml}$ on changing to the newer formulation. In the $0.5 \mathrm{mg} /$ day dosage group the mean level on older Lanoxin was $0.80(S D \pm 0.33)$ $\mathrm{ng} / \mathrm{ml}$ and a more pronounced increase to $\mathrm{I} \cdot 52$ $(\mathrm{SD} \pm 0.6 \mathrm{I}) \mathrm{ng} / \mathrm{ml}$ was seen when newer Lanoxin was used. The 2 patients in the $0.75 \mathrm{mg} /$ day group increased from $\mathrm{I} \cdot \mathrm{I} \pm 0.28$ to $2 \cdot 05 \pm 0.07 \mathrm{ng} / \mathrm{ml}$.

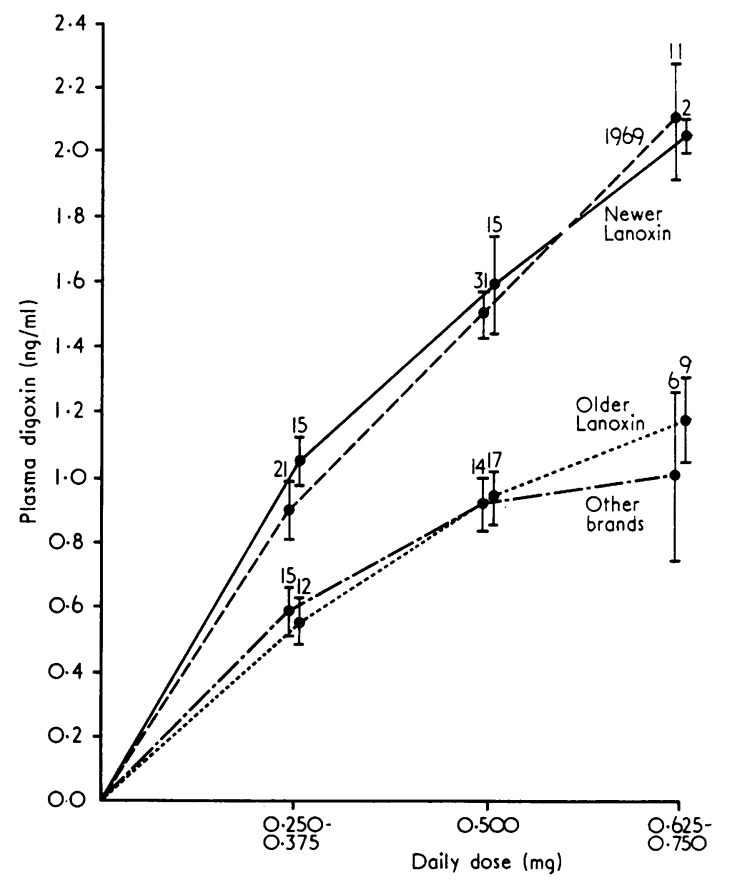

FIG. Digoxin levels (mean $\pm S E$ ) recorded in patients with normal or near normal renal function during use of the older and newer Lanoxin, and other brands. The line marked 1969 gives the levels found by Chamberlain et al. (1970) of work done in 1969 in patients using Lanoxin. The numbers in the figure give the total patients in each group. 
TABLE I Mean ( \pm standard error) digoxin levels ( $\mathrm{ng} / \mathrm{ml})$ in patients during use of older and newer Lanoxin and other brands

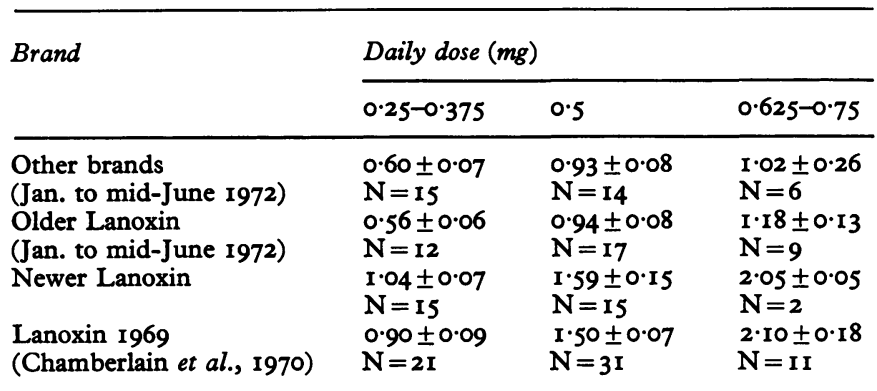

Note: Included in the Table are the levels found by Chamberlain et al. in I969 in patients using Lanoxin. All patients had normal or near-normal renal function.

$\mathrm{N}=$ number of patients in each group.

TABLE 2 Plasma digoxin levels in patients who had used both older and newer Lanoxin: all patients had near normal renal function

\begin{tabular}{|c|c|c|c|c|c|c|}
\hline $\begin{array}{l}\text { Case } \\
\text { No. }\end{array}$ & $\begin{array}{l}\text { Body } \\
\text { weight } \\
(\mathrm{kg})\end{array}$ & $\begin{array}{l}\text { Daily dose } \\
\text { of digoxin } \\
\text { (mg) }\end{array}$ & $\begin{array}{l}\text { Plasma digoxin } \\
\text { when using } \\
\text { older Lanoxin } \\
(\mathrm{ng} / \mathrm{ml})\end{array}$ & $\begin{array}{l}\text { Plasma digoxin } \\
\text { when using } \\
\text { newer Lanoxin } \\
(\text { ng/ml) }\end{array}$ & $\begin{array}{l}\text { Percentage } \\
\text { change } \\
\text { (older Lanoxin } \\
\text { level }=I O 0 \text { ) }\end{array}$ & $\begin{array}{l}\text { Calculated } \\
\text { level for } \\
0.5 \mathrm{mg} \text { dose } \\
\text { of older } \\
\text { Lanoxin }\end{array}$ \\
\hline I & 65 & 0.25 & 0.6 & $I \cdot I$ & +83 & $I \cdot 2$ \\
\hline 2 & 55 & 0.375 & 0.9 & $I \cdot 4$ & +56 & $I \cdot 2$ \\
\hline 3 & 52 & 0.375 & 0.7 & $I \cdot 5$ & +71 & $1 \cdot 3$ \\
\hline 4 & 50 & 0.25 & $I \cdot 0$ & $I \cdot 2$ & +50 & $\mathrm{I} \cdot 4$ \\
\hline 5 & 43 & 0.25 & $1 \cdot 0$ & $1 \cdot 0$ & 0 & $2 \cdot 0$ \\
\hline 6 & 67 & 0.25 & $I \cdot 0$ & 0.8 & -20 & $2 \cdot 0$ \\
\hline 7 & 70 & 0.5 & 0.25 & 0.8 & +220 & 0.25 \\
\hline 8 & 93 & 0.5 & 0.5 & $I \cdot 2$ & +140 & 0.5 \\
\hline 9 & 60 & 0.5 & 0.6 & 2.5 & +317 & 0.6 \\
\hline I0 & 63 & 0.5 & 0.6 & 0.9 & +50 & 0.6 \\
\hline I I & 58 & 0.5 & 0.7 & $1 \cdot 7$ & +143 & 0.7 \\
\hline I2 & 68 & 0.5 & 0.8 & $1 \cdot 5$ & +88 & 0.8 \\
\hline 13 & 71 & 0.5 & 0.8 & $I \cdot 3$ & +63 & 0.8 \\
\hline 14 & 60 & 0.5 & $I \cdot O$ & $I \cdot 4$ & +40 & $I \cdot 0$ \\
\hline 15 & 55 & 0.5 & $I \cdot O$ & $I \cdot 0$ & 0 & $I \cdot 0$ \\
\hline 16 & 32 & 0.5 & $1 \cdot 3$ & $2 \cdot 7$ & +108 & $I \cdot 3$ \\
\hline 17 & 80 & 0.5 & $1 \cdot 3$ & $I \cdot 7$ & +31 & $1 \cdot 3$ \\
\hline 18 & 70 & 0.75 & 0.9 & $2 \cdot I$ & +133 & 0.6 \\
\hline 19 & 85 & 0.75 & $1 \cdot 3$ & $2 \cdot 0$ & +54 & 0.9 \\
\hline \multicolumn{3}{|c|}{ Mean \pm SD for total group } & $0.86 \pm 0.28$ & $1.46 \pm 0.54$ & & \\
\hline
\end{tabular}

*Note: The last column shows the digoxin levels calculated for a $0.5 \mathrm{mg} /$ day dose by multiplying the recorded level by the factor $0.5 /$ dose used.

\section{Dissolution rate of tablets}

The in vitro dissolution rate of the older and newer Lanoxin and the 15 other brands are given in Table 4. The dissolution rate in the other brands ranged from 33 per cent to II8 per cent of the stated dose in the tablets. Three had a dissolution rate of more than 80 per cent at $\mathrm{I}$ hour.

\section{Discussion}

The newer Lanoxin tablets clearly give higher 
TA BLE 3 Plasma digoxin levels ( $\mathrm{ng} / \mathrm{ml}$ ) recorded with older and newer Lanoxin in patients using $0.25-0.375 \mathrm{mg}$, $0.5 \mathrm{mg}$, and $0.75 \mathrm{mg}$ per day: all had blood urea $<40 \mathrm{mg} / 100 \mathrm{ml}$

\begin{tabular}{|c|c|c|c|c|}
\hline $\begin{array}{l}\text { Daily } \\
\text { Digoxin } \\
\text { dosage } \\
\text { (mg/day) }\end{array}$ & $\begin{array}{l}\text { Body } \\
\text { weight } \\
(\mathrm{kg}) \\
(\text { mean } \pm S D)\end{array}$ & $\begin{array}{l}\text { Digoxin } \\
\text { level on } \\
\text { older Lanoxin } \\
(\text { mean } \pm S D)\end{array}$ & $\begin{array}{l}\text { Digoxin } \\
\text { level on } \\
\text { newer Lanoxin } \\
(\text { mean } \pm S D)\end{array}$ & $\begin{array}{l}\text { Percentage } \\
\text { increase }\end{array}$ \\
\hline $\begin{array}{l}0.25-0.375 \\
\mathrm{~N}=6\end{array}$ & $55 \pm 9$ & $0.87 \pm 0.18$ & $I \cdot 17 \pm 0 \cdot 26$ & 35 \\
\hline $\begin{array}{l}0.5 \\
N=I I\end{array}$ & $65 \pm 15$ & $0.80 \pm 0.33$ & $I .5 I \pm 0.6 I$ & 89 \\
\hline $\begin{array}{l}0 \cdot 75 \\
N=2\end{array}$ & $78 \pm \mathrm{II}$ & $I \cdot 10 \pm 0.28$ & $2.05 \pm 0.07$ & 85 \\
\hline
\end{tabular}

TABLE 4 Dissolution rates of digoxin tablets of older Lanoxin, newer Lanoxin, and 15 other brands

\begin{tabular}{ll} 
Brand & $\begin{array}{l}\text { Percentage } \\
\text { of stated dose } \\
\text { in solution } \\
\text { after } \text { I hour }\end{array}$ \\
\hline Older Lanoxin & 44 \\
Newer Lanoxin & 97 \\
A & 37 \\
B & 42 \\
C & 43 \\
D & 56 \\
F & 33 \\
G & 72 \\
H & 65 \\
I & 118 \\
J & 99 \\
K & 52 \\
L & 65 \\
N & 50 \\
O & 87 \\
\hline
\end{tabular}

steady-state levels than the tablets made shortly before the recent change in manufacture. The twothirds increase in the digoxin absorbed from Lanoxin tablets is less than the twofold increase suggested in the initial warning letter sent by Burroughs Wellcome to medical practitioners in the United Kingdom (British Medical fournal, 1972). Whiting, Rodger, and Sumner (1972) have also reported a less than twofold increase, but Stewart and Simpson (1972) found that mean levels of digoxin from the newer Lanoxin were more than twice those seen with the older formulation.

The digoxin levels found with the newer Lanoxin are similar to those recorded in 1969 when patients using Lanoxin were studied by Chamberlain and his co-workers (Chamberlain et al., r970; D. A. Chamberlain, 1972, personal communication). This is explained by the fact that an initial adjustment of the manufacture of Lanoxin was made in autumn I969 (A. D. Munro-Faure, I972, personal communication). It now appears that the result of this adjustment was to reduce the biological availability of Lanoxin. The recent amendment in the manufacturing process has restored the biological availability of the tablets to their 1969 level. The newer Lanoxin seems to produce nearly maximal absorption of the digoxin since the levels obtained with the newer tablets are comparable to those found when tritiated digoxin was given with a daily dosage of a liquid preparation (Marcus et al., 1966).

The range of steady-state plasma levels at which digoxin is usually effective is I to $2 \mathrm{ng} / \mathrm{ml}$. Our results show that most patients with normal or near normal renal function did not achieve a digoxin level greater than I ng/ml when using 0.25 to $0.5 \mathrm{mg} /$ day of the older Lanoxin or the average other brand. With the newer Lanoxin, as with the r969 Lanoxin, levels of I to $2 \mathrm{ng} / \mathrm{ml}$ were usually obtained with a daily dosage of 0.25 to $0.5 \mathrm{mg} /$ day. We therefore recommend that the newer Lanoxin be used in the traditional dosages of $0.25-0.5 \mathrm{mg} /$ day for patients of normal size and renal function.

When older Lanoxin was replaced by newer Lanoxin the increase in digoxin level varied considerably from patient to patient. Some patients achieved high levels with older Lanoxin despite its slow dissolution rate; these patients were usually in the $0.25 \mathrm{mg} /$ day group. Larger differences, up to fourfold, tended to occur in patients who had low levels relative to the dose of older Lanoxin. The range of levels recorded during use of older Lanoxin cannot be wholly explained by differences in body weight and renal function but presumably reflects individual variation in the ability to absorb from slowly dissolving digoxin tablets. When comparing older Lanoxin to other brands we found a similar individual variation, with changes in digoxin level most pronounced in those who were poor digoxin 
absorbers (Shaw et al., 1972). The findings of Falch, Teien, and Bjerkelund (1973) may be explained in this way. The patients in their maintenance therapy group were using $0.25 \mathrm{mg} /$ day of older Lanoxin and had a high mean digoxin level of $0.94 \mathrm{ng} / \mathrm{ml}$. This increased to only $\mathrm{I} .03 \mathrm{ng} / \mathrm{ml}$ with newer Lanoxin, though in single-dose studies in other subjects these workers showed a much higher absorption with the newer Lanoxin. Their data also show a wide variation in digoxin absorption between individuals. In their single dose studies the ratio of absorption from older Lanoxin to that of newer Lanoxin varied from I.I to 5.2.

This variation between different patients means that no fixed ratio of dose equivalence can be used when a patient is changed from slowly dissolving tablets to quickly dissolving tablets. We suggest that when a patient is changed to newer Lanoxin the dosage should be reassessed on the usual criteria of renal function, body size, plasma potassium level, and thyroid function.

During the period autumn 1969 to mid-1972, the biological availability of Lanoxin was equivalent to the average other brand. Since mid-1972, however, there has been a pronounced difference between Lanoxin tablets and the tablets of most other manufacturers. For this reason, the Pharmaceutical Society advised pharmacists to dispense Lanoxin only when it was specified (Pharmaceutical fournal, I972).

Are all the other brands of digoxin tablets of equivalent biological availability ? There have been over 20 different brands available in the United Kingdom and in the absence of specific studies of each brand in human beings this question cannot be answered. At present only the results of in vitro tests on the tablets are available for the majority of brands. The disintegration time test, previously used, measures the time required for tablets immersed in a solution to break down to granules small enough to escape through a sieve. Both the older and newer Lanoxin tablets come within the requirements of this test and it is now accepted as an inadequate test of biological availability for digoxin. The dissolution rate test measures the speed at which the drug contained in the tablets enters into solution, and has recently been shown to be a good index of biological availability (Lindenbaum et al., 1973; Johnson et al., 1973). The wide variation in dissolution rate found in the brands tested indicates that they are far from equivalent in efficacy. Beckett and Cowan (I973) have also found a wide range of dissolution rates in a group of brands of digoxin tablets.

The existence of digoxin tablets of different and sometimes unknown efficacy continues to cause difficulties in management. Improved precision and safety in digoxin treatment require all digoxin tablets to be of equivalent biological availability. For this to be achieved there is a need for further knowledge of the factors in manufacturing, which influence bioavailability, and new standards for quality control of each batch produced.

We are grateful to the physicians and surgeons of St. Bartholomew's Hospital for allowing us to report the findings in patients under their care.

We also thank Dr. W. R. L. Brown and Miss M. Hodges of the Pharmacy Department for their help and advice.

M.R.H. is in receipt of a grant from the British Heart Foundation.

\section{References}

Beckett, A. H., and Cowan, D. A. (1973). Differences in the dissolution rate of generic digoxin tablets. Pharmaceutical fournal, 21I, III.

British Medical fournal (1972). Dosage of digoxin (Medical News). 3, 427.

Chamberlain, D. A., White, R. J., Howard, M. R., and Smith, T. W. (1970). Plasma digoxin concentrations in patients with atrial fibrillation. British Medical fournal, 3, 429.

Falch, D., Teien, A., and Bjerkelund, C. J. (1973). Comparative study of the absorption, plasma levels, and urinary excretion of the 'new' and 'old' Lanoxin. British Medical fournal, $1,695$.

Fraser, E. J., Leach, R. H., and Poston, J. W. (1972). Bioavailability of digoxin. Lancet, 2, 54I.

Johnson, B. F., Greer, H., McCrerie, J., Bye, C., and Fowle, A. (1973). Rate of dissolution of digoxin tablets as a predictor of absorption. Lancet, I, 1473 .

Lancet (1972). The bioavailability of digoxin, 2, $31 \mathrm{I}$.

Lindenbaum, J., Butler, V. P., Murphy, J. E., and Cresswell, R. M. (1973). Correlation of digoxin-tablet dissolutionrate with biological availability. Lancet, I, I2I5.

Lindenbaum, J., Mellow, M. H., Blackstone, M. O., and Butler, V. P. (1971). Variation in biologic availability of digoxin from four preparations. New England fournal of Medicine, 285, 1344 .

Manninen, V., Melin, J., and Härtel, G. (197I). Serumdigoxin concentrations during treatment with different preparations. Lancet, 2, 934.

Marcus, F. I., Burkhalter, L., Cuccia, C., Pavlovich, J., and Kapadia, G. G. (1966). Administration of tritiated digoxin with and without a loading dose: a metabolic study. Circulation, 34, 865.

Pharmaceutical fournal (1972). Lanoxin potency doubled. 209, 133.

Shaw, T. R. D., Howard, M. R., and Hamer, J. (1972). Variation in the biological availability of digoxin. Lancet, 2, 303.

Stewart, M. J., and Simpson, E. (1972). New formulation of Lanoxin: expected plasma levels of digoxin. Lancet, 2, $54 \mathrm{I}$.

Whiting, B., Rodger, J. C., and Sumner, D. J. (1972). New formulation of digoxin. Lancet, 2, 922 .

Requests for reprints to Dr. T. R. D. Shaw, Department of Cardiology, St. Bartholomew's Hospital, London ECIA $7 \mathrm{BE}$. 